\title{
DAMPAK GUDGET TERHADAP PERKEMBANGAN BAHASA ANAK USIA DINI
}

\author{
Yulsyofriend $^{1}$, Vivi Anggraini ${ }^{2}$, Indra Yeni ${ }^{3}$. \\ Universitas Negeri Padang \\ Email: yulsyofriend@ fip.unp.co.id
}

\begin{abstract}
ABSTRAK
ICT (Information and Communication Technologies) adalah payung besar terminologi yang mencakup seluruh peralatan teknis untuk memproses dan menyampaikan informasi. Gudget adalah salah satu dari ICT yang sangat berperan penting terhadap perkembangan anak usia dini. Sesuai dengan tujuan utama pendidikan anak usia dini adalah untuk mengembangkan seluruh aspek perkembangan anak usia dini dengan memberikan stimulus-stimulus berupa kegiatan bermain yang menyenangkan dan mampu mengintegrasikan kemampuan anak usia dini secara optimal. Perkembangan Bahasa pada anak usia dini merupakan hal yang paling berfungsi dan berperan dalam kehidupan anak. Namun dengan adanya penggunaan gudged memiliki pengaruh terhadap keterampilan berbahasa anak yang mencakup dalam memperoleh keterampilan berbahasa, biasanya melalui suatu hubungan urutan yang teratur: pembiasaan pada masa kecil, belajar menyimak/mendengarkan bahasa, kemudian berbicara, membaca, dan menulis. Namun dengan menggunakan gudget berdampak terhadap keterlambatan dalam berbicara anak hal ini disebabkan karena gudget menghambat komunikasi langsung terhadap lingkungan sekitar.
\end{abstract}

Kata Kunci: Gudget, Perkembangan bahasa, dan Anak Usia Dini

\begin{abstract}
Information and Communication Technologies (ICT) is a large of terminology that covers all technical equipment to process and convey information. Gudgets are one of the most important ICTs for early childhood development. In accordance with the main purpose of early childhood education is to develop all aspects of early childhood development by providing stimuli in the form of play activities that are able to integrate early childhood abilities optimally. Language development in early childhood is the most function and role in life. However, with the use of gudged has a major influence on children's language skills that include language. In acquiring language skills we usually go through a regular sequence relationship: first, in childhood, we learn to listen I listen to language, then speak, read, and write.
\end{abstract}

Keywords: Gudget, Language Development, and Early Childhood 
PENDAHULUAN

Di era globalisasi anak usia dini tidak dapat terlepas dari ICT atau TIK yang selalu berada di lingkungan anak. Teknologi Informasi dan Komunikasi / TIK (Information and Communication Technologies / ICT) adalah payung besar terminologi yang mencakup seluruh peralatan teknis untuk memproses dan menyampaikan informasi. TIK mencakup dua aspek yaitu teknologi informasi dan teknologi komunikasi. Teknologi informasi meliputi segala hal yang berkaitan dengan proses, penggunaan sebagai alat bantu, manipulasi, dan pengelolaan informasi. Sedangkan teknologi komunikasi adalah segala sesuatu yang berkaitan dengan penggunaan alat bantu untuk memproses dan mentransfer data dari perangkat yang satu ke lainnya. Memang benar bahwa TIK mempunyai kelebihan dalam mendapatkan informasi yang di dapat dimana saja dan kapan saja. Namun kita tidak bisa melihat perkembangan dan peranan TIK dari satu prespektif saja. Ketika kita melihat dari prespektif lain terlihat bahwa terdapat ketimpangan sosial dan berbagai masalah yang terdapat pada penggunaan TIK pada anak usia dini. Gudget adalah salah satu dari ICT yang sangat berperan penting terhadap perkembangan anak usia dini.

Tujuan utama pendidikan anak usia dini adalah untuk mengembangkan seluruh aspek perkembangan anak usia dini dengan memberikan stimulus-stimulus berupa kegiatan bermain yang mampu mengintegrasikan kemampuan anak usia dini secara optimal. Gudged memberikan wahana-wahana bermain yang sangat menarik minat anak baik dari segi warna, suara, dan jenis permainan yang menantang sehingga anak tertarik dengan permainan tersebut. Masalahnya adalah karena gudged merupakan sistem komunikasi satu arah tentu saja kita tidak akan bisa melihat umpan balik yang diberikan oleh anak, sehingga kemampuan bahasa anak kurang berkembangang. Selanjutnya dari segi fisik, karena penggunaan gudged yang notabene nya kegiatan yang dilakukan anak hanya duduk pasif sehingga gerak motorik kasar dan halus tidak dapat terstimulasi. Karena aspek perkembangan tersebut terintegrasi satu dengan yang lain sehingga akan sulit untuk mengembangkan aspek lainnya.

\section{PEMBAHASAN}

\section{Pengertian Anak Usia Dini}

Proses perkembangan manusia secara utuh telah dimulai sejak dalam kandungan ibunya dan memasuki usia emas (the golden age) hingga usia 6 tahun, hal ini merupakan masa peka bagi anak sehingga para ahli menyebutnya the golden age, karena perkembangan kecerdasaanya 
mengalami peningkatan yang sangat signifikan. Mengingat masa ini merupakan usia emas, maka perlu ditulis dengan tinta emas, dengan tulisan-tulisan yang dapat menghasilkan emas dimasa mendatang. Pada masa ini pematangan fungsi-fungsi fisik dan psikis yang siap merespon stimulasi yang datang dari lingkunganya.: Anak usia dini adalah individu yang sedang mengalami proses pertumbuhan dan perkembangan yang sangat pesat, bahkan dikatakan sebagai lompatan perkembangan (Mulyasa, 2012 :16) . Anak usia dini memiliki rentang usia yang sangat berharga dibanding usiausia selanjunya karena perkembangan kecerdasannya sangat luar biasa. Usia tersebut merupakan fase kehidupan yang unik, dan berada pada proses perubahan berupa pertumbuhan, perkembangan, pematangan dan penyempurnaan, pada aspek jasmani maupun rohaninya yang berlangsung seumur hidup, bertahap, dan berkesinambungan. Masa manusia memiliki keunikan yang perlu diperhatikan orang dewasa, anak usia dini unik dalam potensi yang dimiliki dan pelayanan yang sungguh-sungguh agar setiap potensi dapat menjadi landasan dalam menapaki tahap perkembangan berikutnya. Selanjutnya Mutiah Anak usia dini merupakan usia yang memiliki rentangan waktu sejak lahir hingga usia enam tahun, dimana dilakukan melalui pemberian ransangan pendidikan untuk membantu pertumbuhan dan perkembangan jasmani dan rohani agar anak memiliki kesiapan dalam memasuki pendidikan lebih lanjut (Mutiah, 2012: 2).

Penulis dapat menyimpulkan bahwa anak usia dini adalah individu yang sedang mengalami proses pertumbuhan dan perkembangan yang sangat pesat, bahkan dikatakan sebagai lompatan perkembangan dan pada masa ini anak memiliki keunikan yang perlu diperhatikan untuk memasuki jenjang pendidikan yang lebih lanjut.

2. Hakikat Perkembangan Anak Usia Dini

a. Prinsip Perkembangan

\begin{tabular}{lcr}
\multicolumn{2}{c}{ Sebelum } & \multicolumn{2}{r}{ kelahiran, } \\
pertumbuhan & fisik & dan \\
perkembangan & mengikuti & prinsip \\
cephalocaudal & dan & prinsip \\
proximodistal & (Papalia, & 2012 :
\end{tabular} 115). Menurut prinsip cephalocaudal, pertumbuhan terjadi dari atas ke bawah. Karena otak tumbuh dengan cepat sebelum lahir, kepala bayi yang baru lahir adalah proporsional besar. Kepala menjadi proporsional lebih kecil sebagai anak tumbuh tinggi dan bagian bawah tubuh mengembangkan). Sensorik dan perkembangan motorik melanjutkan sesuai dengan prinsip yang sama; bayi belajar menggunakan bagian atas tubuh mereka sebelum bagian bawah. Anak melihat benda-benda sebelum mereka dapat 
mengendalikan batang otak mereka, dan mereka belajar untuk melakukan banyak hal dengan tangan mereka jauh sebelum mereka bisa merangkak atau berjalan.

$$
\text { Menurut prinsip }
$$

proximodistal (dalam ke luar), pertumbuhan dan perkembangan motorik melanjutkan dari pusat tubuh. Di dalam rahim, kepala dan batang berkembang sebelum lengan dan kaki, kemudian tangan dan kaki, dan kemudian jari tangan dan kaki. Selama masa bayi dan anak usia dini pertama mengembangkan kemampuan untuk menggunakan lengan atas dan kaki bagian atas (yang ditutup ke pusat tubuh), kemudian lengan dan kaki depan mereka, lalu tangan dan kaki, dan akhirnya, jari tangan dan kaki.

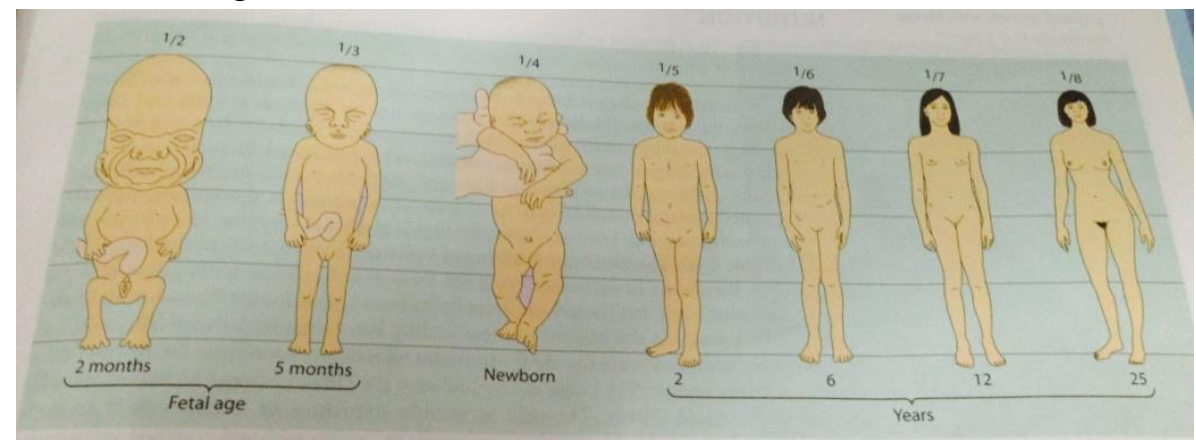

Gambar 1: perubahan proporsi dari pertumbuhan tubuh manusia. Sumber : Buku Experience Human Development, 2012

Keterangan: perubahan yang paling terlihat adalah bahwa kepala menjadirelatif lebih kecil ke seluruh tubuh. Fraksi menunjukkan ukuran kepala kepala sebagai proporsi dari total panjang tubuh di beberapa usia. Lebih lanjut adalah stabilitas proporsi batang (dari leher ke selangkangan). Meningkatnya proporsi kaki hampir persis kebalikan dari proporsi kepala menurun.

\section{b. Tipe Perkembangan}

Tipe perkembangan terbagi menjadi delapan periode dari perkembangan manusia (Papalia, 2012: 8-9) :

\begin{tabular}{|l|l|l|l|}
\hline Periode usia & Perkembangan fisik & \multicolumn{1}{|c|}{$\begin{array}{c}\text { Perkembangan } \\
\text { kognitif }\end{array}$} & $\begin{array}{c}\text { Perkembangan } \\
\text { psikososial }\end{array}$ \\
\hline $\begin{array}{l}\text { Periode prenatal } \\
\text { (konsepsi hingga } \\
\text { kelahiran) }\end{array}$ & $\begin{array}{l}\text { Konsepsi terjadi } \\
\text { dengan pembuahan } \\
\text { normal atau cara lain. } \\
\text { Genetik berinteraksi } \\
\text { dengan pengaruh }\end{array}$ & $\begin{array}{l}\text { Kemampuan untuk } \\
\text { belajar dan mengingat } \\
\text { dan untuk menanggapi } \\
\text { rangsangan sensorik } \\
\text { berkembang }\end{array}$ & $\begin{array}{l}\text { Janin merespon suara } \\
\text { ibu dan } \\
\text { mengembangkan } \\
\text { preferensi tersebut. }\end{array}$ \\
\hline
\end{tabular}




\begin{tabular}{|c|c|c|c|}
\hline & $\begin{array}{l}\text { lingkungan dari awal. } \\
\text { Struktur dasar tubuh } \\
\text { dan bentuk organ: } \\
\text { otak percepatan } \\
\text { pertumbuhan dimulai. } \\
\text { Pertumbuhan fisik } \\
\text { adalah yang paling } \\
\text { cepat dalam rentang } \\
\text { kehidupan. } \\
\text { Hal ini sangat rentan } \\
\text { terhadap pengaruh } \\
\text { lingkungan yang } \\
\text { besar. }\end{array}$ & & \\
\hline $\begin{array}{l}\text { Bayi dan balita } \\
\text { (lahir sampai } \\
\text { usia 3) }\end{array}$ & $\begin{array}{l}\text { Semua indera dan } \\
\text { sistem tubuh } \\
\text { beroperasi pada } \\
\text { kelahiran. } \\
\text { Otak tumbuh dalam } \\
\text { kompleksitas dan } \\
\text { sangat sensitif } \\
\text { terhadap pengaruh } \\
\text { lingkungan. } \\
\text { Pertumbuhan fisik } \\
\text { dan perkembangan } \\
\text { keterampilan motorik } \\
\text { yang cepat }\end{array}$ & $\begin{array}{l}\text { Kemampuan untuk } \\
\text { belajar dan mengingat, } \\
\text { penggunaan simbol dan } \\
\text { kemampuan untuk } \\
\text { memecahkan masalah } \\
\text { berkembang pada akhir } \\
\text { tahun kedua. } \\
\text { Pemahaman dan } \\
\text { penggunaan bahasa } \\
\text { berkembang dengan } \\
\text { cepat }\end{array}$ & $\begin{array}{l}\text { Kesadaran diri } \\
\text { berkembang. Bergeser } \\
\text { dari ketergantungan } \\
\text { terhadap otonomi } \\
\text { terjadi (kemandirian } \\
\text { mulai berkembang). } \\
\text { Minat anak-anak } \\
\text { terhadap hal-hal lain } \\
\text { meningkat. }\end{array}$ \\
\hline $\begin{array}{l}\text { Anak usia dini } \\
\text { (usia } 3 \text { sampai 6) }\end{array}$ & $\begin{array}{l}\text { Pertumbuhan stabil: } \\
\text { penampilan menjadi } \\
\text { lebih proporsi yang } \\
\text { kearah hal lebih } \\
\text { dewasa. Adanya } \\
\text { masalah tidur yang } \\
\text { umum. } \\
\text { Keinginan muncul: } \\
\text { keterampilan motorik } \\
\text { halus dan kasar dan } \\
\text { kekuatan } \\
\text { meningkatkan }\end{array}$ & $\begin{array}{l}\text { Berpikir agak egosentris, } \\
\text { tetapi pemahaman } \\
\text { tentang perspektif orang } \\
\text { lain tumbuh. } \\
\text { Ketidakdewasaan } \\
\text { kognitif menghasilkan } \\
\text { beberapa ide yang tidak } \\
\text { logis tentang dunia. } \\
\text { Memori dan bahasa } \\
\text { meningkatkan. } \\
\text { Intelijen menjadi lebih } \\
\text { mudah diprediksi } \\
\text { pengalaman prasekolah } \\
\text { adalah umum, dan } \\
\text { pengalaman TK }\end{array}$ & $\begin{array}{l}\text { Konsep diri dan } \\
\text { pemahaman emosi } \\
\text { menjadi lebih } \\
\text { kompleks: harga diri } \\
\text { adalah global, } \\
\text { kemandirian, inisiatif, } \\
\text { dan meningkatkan } \\
\text { kontrol diri. } \\
\text { Identitas gender } \\
\text { berkembang. Bermain } \\
\text { menjadi lebih } \\
\text { imajinatif yang lebih } \\
\text { rumit, dan biasanya } \\
\text { lebih social.altruism, } \\
\text { agresi dan fearfulness } \\
\text { yang umum. } \\
\text { Keluarga masih fokus } \\
\text { kehidupan sosial, } \\
\text { tetapi anak-anak lain } \\
\text { menjadi lebih } \\
\text { penting. }\end{array}$ \\
\hline $\begin{array}{l}\text { Masa tengah } \\
\text { (usia } 6 \text { sampai } \\
\text { 11) }\end{array}$ & $\begin{array}{l}\text { Pertumbuhan } \\
\text { melambat. } \\
\text { Kekuatan dan } \\
\text { keterampilan atletik } \\
\text { meningkatkan. } \\
\text { Penyakit pernapasan } \\
\text { yang umum, tetapi } \\
\text { kesehatan umumnya }\end{array}$ & $\begin{array}{l}\text { Egosentrisme berkurang. } \\
\text { Anak-anak mulai } \\
\text { berpikir secara logis tapi } \\
\text { konkret. } \\
\text { Memori dan kemampuan } \\
\text { bahasa meningkat. } \\
\text { Keuntungan kognitif } \\
\text { mengizinkan anak-anak }\end{array}$ & $\begin{array}{l}\text { Konsep diri menjadi } \\
\text { lebih kompleks, yang } \\
\text { mempengaruhi harga } \\
\text { diri. Regulasi diri } \\
\text { mencerminkan } \\
\text { pergeseran bertahap } \\
\text { dalam kontrol dari } \\
\text { orang tua ke anak. }\end{array}$ \\
\hline
\end{tabular}




\begin{tabular}{|c|c|c|c|}
\hline & $\begin{array}{l}\text { lebih baik dari pada } \\
\text { waktu lainnya dalam } \\
\text { rentang kehidupan. }\end{array}$ & $\begin{array}{l}\text { untuk mendapatkan } \\
\text { keuntungan dari } \\
\text { pendidikan formal. } \\
\text { Beberapa anak } \\
\text { menunjukkan kebutuhan } \\
\text { pendidikan khusus dan } \\
\text { kekuatan. }\end{array}$ & \\
\hline $\begin{array}{l}\text { Remaja (usia } 11 \\
\text { sampai 20) }\end{array}$ & $\begin{array}{l}\text { Pertumbuhan fisik } \\
\text { dan serta tubuh } \\
\text { perubahan lainnya } \\
\text { yang cepat dan } \\
\text { mendalam. } \\
\text { Kematangan } \\
\text { reproduksi. } \\
\text { Risiko kesehatan } \\
\text { utama timbul dari } \\
\text { masalah perilaku, } \\
\text { seperti gangguan } \\
\text { makan dan } \\
\text { penyalahgunaan } \\
\text { narkoba. }\end{array}$ & $\begin{array}{l}\text { Kemampuan untuk } \\
\text { berpikir secara abstrak } \\
\text { dan menggunakan } \\
\text { penalaran ilmiah } \\
\text { berkembang. } \\
\text { Berpikir dewasa tetap } \\
\text { dalam beberapa sikap } \\
\text { dan perilaku. } \\
\text { Pendidikan berfokus } \\
\text { pada persiapan } \\
\text { perguruan tinggi. }\end{array}$ & $\begin{array}{l}\text { Pencarian identitas } \\
\text { termasuk identitas } \\
\text { seksual, menjadi } \\
\text { pusat. } \\
\text { Hubungan dengan } \\
\text { orang tua umumnya } \\
\text { baik. } \\
\text { Kelompok teman } \\
\text { dapat memberikan } \\
\text { pengaruh positif atau } \\
\text { negatif. }\end{array}$ \\
\hline $\begin{array}{l}\text { Dewasa yang } \\
\text { baru muncul dan } \\
\text { muda (usia } 20 \\
\text { sampai 40) }\end{array}$ & $\begin{array}{l}\text { Kondisi puncak fisik, } \\
\text { kemudian menurun } \\
\text { sedikit. } \\
\text { Pilihan gaya hidup } \\
\text { mempengaruhi } \\
\text { kesehatan. }\end{array}$ & $\begin{array}{l}\text { Berpikir dan penilaian } \\
\text { moral menjadi lebih } \\
\text { kompleks. } \\
\text { Pilihan pendidikan dan } \\
\text { pekerjaan yang dibuat. } \\
\text { Kadang-kadang setelah } \\
\text { masa eksplorasi. }\end{array}$ & $\begin{array}{l}\text { Ciri-ciri kepribadian } \\
\text { dan gaya hidup } \\
\text { menjadi relatif stabil. } \\
\text { Tapi perubahan } \\
\text { kepribadian dapat } \\
\text { dipengaruhi oleh tahap } \\
\text { kehidupan dan } \\
\text { peristiwa. } \\
\text { Hubungan intim dan } \\
\text { gaya hidup pribadi } \\
\text { ditetapkan tetapi tidak } \\
\text { dapat berlangsung. } \\
\text { Kebanyakan orang } \\
\text { menikah dan menjadi } \\
\text { orang tua. }\end{array}$ \\
\hline $\begin{array}{l}\text { Dewasa tengah } \\
\text { (usia 40-65) }\end{array}$ & $\begin{array}{l}\text { Perkembangan } \\
\text { kemampuan sensorik } \\
\text { lambat, kesehatan, } \\
\text { stamina, dan } \\
\text { kekuatan mungkin } \\
\text { mulai, tetapi } \\
\text { perbedaan individu } \\
\text { lebar. Wanita } \\
\text { mengalami } \\
\text { menopause. }\end{array}$ & $\begin{array}{l}\text { Kemampuan mental } \\
\text { memuncak: keahlian } \\
\text { dan masalah praktis } \\
\text { keterampilan } \\
\text { pemecahan yang tinggi. } \\
\text { Output kreatif mungkin } \\
\text { menurun tetapi } \\
\text { meningkatkan kualitas. } \\
\text { Untuk beberapa, } \\
\text { kesuksesan karir dan } \\
\text { kekuatan produktif } \\
\text { puncak; } \\
\text { untuk orang lain, } \\
\text { kelelahan atau } \\
\text { perubahan karir } \\
\text { mungkin terjadi. }\end{array}$ & $\begin{array}{l}\text { Rasa identitas terus } \\
\text { berkembang; transisi } \\
\text { paruh baya mungkin } \\
\text { terjadi. Tanggung } \\
\text { jawab ganda merawat } \\
\text { anak-anak dan orang } \\
\text { tua dapat } \\
\text { menyebabkan stres. }\end{array}$ \\
\hline $\begin{array}{l}\text { Akhir dewasa } \\
\text { (usia } 65 \text { dan } \\
\text { lebih) }\end{array}$ & $\begin{array}{l}\text { Kebanyakan orang } \\
\text { sehat dan aktif, } \\
\text { meskipun } \\
\text { kemampuan }\end{array}$ & $\begin{array}{l}\text { Kebanyakan orang } \\
\text { waspada secara mental. } \\
\text { Meskipun kecerdasan } \\
\text { dan memori mungkin }\end{array}$ & $\begin{array}{l}\text { Pensiun dari tenaga } \\
\text { kerja dapat terjadi dan } \\
\text { mungkin menawarkan } \\
\text { pilihan baru untuk }\end{array}$ \\
\hline
\end{tabular}




\begin{tabular}{|l|l|l|l|}
\hline & $\begin{array}{l}\text { kesehatan dan fisik } \\
\text { secara umum } \\
\text { menurun. } \\
\text { Perlambatan waktu } \\
\text { reaksi mempengaruhi } \\
\text { beberapa aspek } \\
\text { fungsi. }\end{array}$ & $\begin{array}{l}\text { memburuk di beberapa } \\
\text { daerah, kebanyakan } \\
\text { orang menemukan cara } \\
\text { untuk mengkompensasi. }\end{array}$ & $\begin{array}{l}\text { penggunaan waktu. } \\
\text { Orang } \\
\text { mengembangkan } \\
\text { strategi yang lebih } \\
\text { fleksibel untuk } \\
\text { mengatasi kerugian } \\
\text { pribadi dan kematian }\end{array}$ \\
& & $\begin{array}{l}\text { yang akan datang. } \\
\text { Mencari makna dalam } \\
\text { kehidupan sangat } \\
\text { penting. }\end{array}$ \\
\hline
\end{tabular}

\section{c. Perkembangan Umum Anak Usia Satu Tahun}

Anak usia satu tahun juga disebut Balita, mereka memiliki akses dan keajaiban dunia perkembangan yang dapat dieksplorasi. Mereka mendapatkan peningkatan keterampilan dalam bergerak, dimulai dengan meluncur, ketika mereka pertama kali mulai berjalan, pada saat mereka berjalan mereka pelahan-lahan sehingga pada tahun kedua akhir itu sudah terlihat stabil dan termasuk berjalan, berjalan mundur, dan menaiki tangga. Mereka juga mulai menggabungkan keterampilan gerak mereka yang baru dikembangkan dengan mendorong dan menarik benda-benda. Mereka mahir memungut benda dan, dengan gembira juga suka untuk menjatuhkan atau membuang benda yang mereka mereka raih. Kendali mereka meningkat dari otot jari sehingga dapat dilihat dalam partisipasi mereka pada waktu makan; mereka menikmati makanan makan dari jari mereka. Memegang sendok, dan minum dari gelas, meskipun upaya ini tidak selalu dinegosiasikan berhasil. Mereka menjadi lebih mandiri, ingin melakukan banyak hal sendiri (Essa, 2011: 34).

Pengasuh anak usia satu tahun harus terus menyediakan lingkungan yang aman, konsisten, sensitif, penuh kasih dan suppportive. Interaksi, konservasi, dan memberi dan menerima bermain antara pengasuh dan anak-anak memberikan kontribusi sangat penting untuk pengembangan balita. Pengasuh juga harus waspada karena balita sangat tertarik tentang segala sesuatu di sekitar mereka dan memiliki kesadaran yang sangat sedikit keselamatan. DAP (Developmentally Approriate Practice) mengatakan bahwa balita mengandalkan pengasuh yang penuh kasih, menciptakan lingkungan yang aman untuk mengeksplorasi, dan memberikan jaminan kepada anak-anak bahwa mereka aman.

Jadwal harian yang disediakan untuk anak usia satu tahun masih ditentukan oleh irama dan kebutuhan individu, tetapi balita mulai menunjukkan kesamaan 
yang lebih besar dalam setiap pola perkembangan mereka sehari-hari; dengan demikian, pengasuh mungkin dapat mengatur jadwal makan dan tidur siang.

\section{d. Perkembangan Umum Anak Usia Dua Tahun.}

Beberapa anak awal memprogram menggabungkan dua-tahun-tahun, terutama yang lebih tua. Ke dalam kelompok prasekolah, sedangkan tempat lain berpasangan dalam kategori balita yang terpisah. Berpasangan berada dalam tahap transisi, membuat pindah dari masa bayi ke masa kecil. Mereka sedang dalam proses mendapatkan dan antusias menggunakan banyak keterampilan baru, terutama dua yang paling jelas menandai perbedaan antara bayi dan anakbahasa dan kontrol motorik.

Selama tahun ini, kebanyakan anak-anak semakin menguasaidalam tubuh mereka berjalan lebih percaya diri dan berjalan yang telah kehilangan stagger bayi, dan dalam kontrol jari baru mereka yang memungkinkan mereka untuk menempatkan teka-teki bersama-sama sederhana atau penggunaan peralatan makan. Adalah beberapa waktu, mereka mengalami pertumbuhan bahasa yang luar biasa. Kosa kata mereka tumbuh, panjang kalimat, dan bentuk-bentuk gramatikal membuka segala macam kemungkinan karena peningkatan kompetensi komunikasi ini, membantu diri sendiri keterampilan juga membaik, termasuk pencapaian toilet training bagi mayoritas anak-anak selama tahun ini, sama pentingnya dengan belajar sensori motor, bahasa, dan self-help adalah proses mendapatkan kemerdekaan melalui penguasaan ini (Essa, 2011: 35).

Usia dua tahun melakukan banyak kegiatan untuk kesenangan semata-mata mereka daripada untuk mencapai tujuan. Berjalan adalah menyenangkan dalam dirinya sendiri dan bukan sebagai sarana untuk mendapatkan suatu tempat cepat; lukisan berarti keterlibatan dalam proses sensorik daripada minat dalam memproduksi gambar, kegiatan juga dilakukan dengan antusias yang sangat besar. Mereka dengan sepenuh hati menceburkan diri ke dalam kegiatan, apakah kegiatan melukis, bermain adonan, menuangkan pasir dan air, atau membaca buku. Mereka sangat menikmati pengalaman sensorik, menggunakan sentuhan, rasa, dan bau, serta penglihatan dan suara. Usia dua tahun terkenal karena mereka berulang keinginan. Menggunakan keterampilan baru yang telah ditemukan. Keinginan ini normal dan harus didorong, 
untuk itu membangun kompetensi dan memungkinkan anak-anak untuk sepenuhnya mengasimilasi keterampilan sebelum pindah ke yang baru.

Usia dua tahun anak mulai mendapatkan beberapa kemampuan sosial, meskipun asosiasi dengan teman-teman lebih ditandai dengan bermain berdampingan daripada berinteraksi. Mereka umumnya tidak terlibat dalam kerjasama dan berbagi. Bahkan, berpasangan, dengan pengendalian diri yang terbatas, hal ini mengungkapkan kebebasan tumbuh dan adanya ketegasan dengan meraih mainan dari teman atau dengan membuat pertengkaran. Perkelahian, adalah kenyataan tidak jarang di antara mereka, hal ini mencerminkan kemampuan verbal mereka yang terbatas, yang belum memadai dapat di mengungkapkan. Apa yang mereka inginkan mereka tidak mahir untuk mengungkapkan; mereka tidak memiliki kemampuan untuk menunggu sesuatu yang mereka inginkan "sekarang".

\section{e. Perkembangan Umum Anak Usia Tiga Tahun}

Anak usia tiga tahun telah benar-benar meninggalkan masa bayi, tidak hanya dalam penampilan tapi bayi juga dalam keterampilan yang berkembang.
Peningkatan keseimbangan dan kontrol yang jelas dalam motorik kasar, motorik halus, dan bagian tubuh lainnya. Usia ini menggunakan keterampilan baru mereka dengan menjadi rata; Namun, mereka kadang-kadang mengalami kecelakaan atau kembali ke perilaku sebelumnya ketika marah. Secara keseluruhan karakteristik mereka menanggapi pengalaman sekolah dengan antusiasme dan kegembiraan. Anak-anak berbicara dapat dimengerti sebagian besar dan terdiri dari kalimat. Bahasa menjadi alat sosial dan kognitif. Usia tiga tahun terlibat dalam percakapan yang lebih luas. Berbicara tidak hanya untuk orang lain namun menjawab serta mengajukan pertanyaan pada kenyataannya, usia tiga tahu biasanya mengucapkan pertanyaan, terus-menerus bertanya "mengapa?" Atau "apa?" Atau "bagaimana datang?" Kosakata terus meningkat dramatis, dan tata bahasa menjadi lebih akurat.

Guru usia tiga tahun perlu menghormati keterampilan tumbuh dan kompetensi. Hal ini penting untuk menjaga kesabaran dan humor yang baik, mengingat bahwa antusiasme yang bertiga menggunakan keterampilan ini tidak selalu cocok dengan akurasi dan kecepatan. Karena usia ini 
$\begin{array}{llr}\text { membantu } & \text { serta } & \begin{array}{r}\text { berlatih } \\ \text { keterampilan }\end{array} \\ \text { kemampuan }\end{array}$ menolong sesama (self help), perilaku tersebut harus dibimbing dan dihargai. Munculnya eksplorasi keterampilan sosial yang aman di saat bermain sendiri atau tidak harus menyerahkan mainan favorit juga diterima. Semua ini merupakan faktor yang kongruen dengan DAP.

\section{Keterampilan Bahasa Anak Dini}

Keterampilan bahasa terbagi menjadi keterampilan mendengarkan (menyimak), berbicara, membaca, dan menulissecara alami kemampuan menyimak dianggap sebagai keterampilan utama dalam akuisisi asli (bahasa pertama). Seorang bayi akan mendengarkan suarasuara dan suaradi lingkungannya untuk diinternalisasi linguistik, sebelum ia/dia berbicara dan belajar membaca dan menulis (Yudi, 2011: 4).

Sedangkan Morrison menyatakan bahasa adalah keterampilan persiapan yang paling penting. Anak membutuhkan keterampilan bahasa untuk dapat berhasil di sekolah dan dalam hidup. Morison, 2012: 223-225): menyatakan bahwa keterampilan bahasa meliputi

1. Bahasa reseptif, seperti mendengarkan guru dan mengikuti petunjuk

2. Bahasa ekspresif, ditunjukkan dalam kemampuan untuk berbicara fasih dan jelas dengan guru dan teman, kemampuan untuk mengekspresikan diri dalam bahasa sekolah, dan kemampuan untuk menyampaikan kebutuhan dan gagasan.

3. Bahasa simbolis, mengetahui nama-nama orang, tempat, dan benda, kata-kata konsep, dan kata sifat dan kata depan

Ketiga keterampilan bahasa itu saling berkait satu sama lain, sehingga untuk mempelajari salah satu keterampilan berbahasa, beberapa keterampilan berbahasa lainnya juga akan terlibat.

Tabel 1

Empat Aspek Keterampilan Bahasa

\begin{tabular}{|l|l|l|}
\hline Ciri-ciri & Lisan & Tulisan \\
\hline Reseptif & Mendengarkan & Membaca \\
\hline Ekspresif & Berbicara & Menulis \\
\hline
\end{tabular}


Dalam memperoleh keterampilan berbahasa biasanya kita melalui suatu hubungan urutan yang teratur: mulamula, pada masa kecil, kita belajar menyimak/mendengarkan bahasa, kemudian berbicara, membaca, dan menulis. Dengan demikian, rangkaian pemerolehan keterampilan berbahasa yaitu keterampilan menyimak, berbicara, membaca, kemudian menulis.

Untuk memiliki pemahaman yang lebih baik mengenai kemampuan menyimak, kita harus mempertimbangkan hal penting terhadap proses menyimak dari teori psikologis. Menurut Brown (2008), berbagai hal yang kita terima dan dengar yang masuk melalui telinga manusia akan ditangkap oleh memori sensorik. Informasi dalam memori jangka pendekakan dilupakan jika tidak
Keterampilan menyimak dan berbicara kita pelajari sebelum memasuki sekolah, sedangkan keterampilan membaca dan menulis pada umumnya dipelajari di sekolah. Keempat aspek keterampilan bahasa berhubungan satu sama lain.

\section{Proses Pemerolehan Bahasa}

berlatih. Melalui latihan yang bisa dilakukan baik dengan cara praktek elaboratif atau menghafal, informasi dapat dikirim melalui memori jangka panjang agar dapat dipertahankan lagi. Model pemrosesan informasi dari memori seperti yang dijelaskan oleh Brown disebut"model Tiga kotak memori." Model memori ditunjukkan pada

Gambar

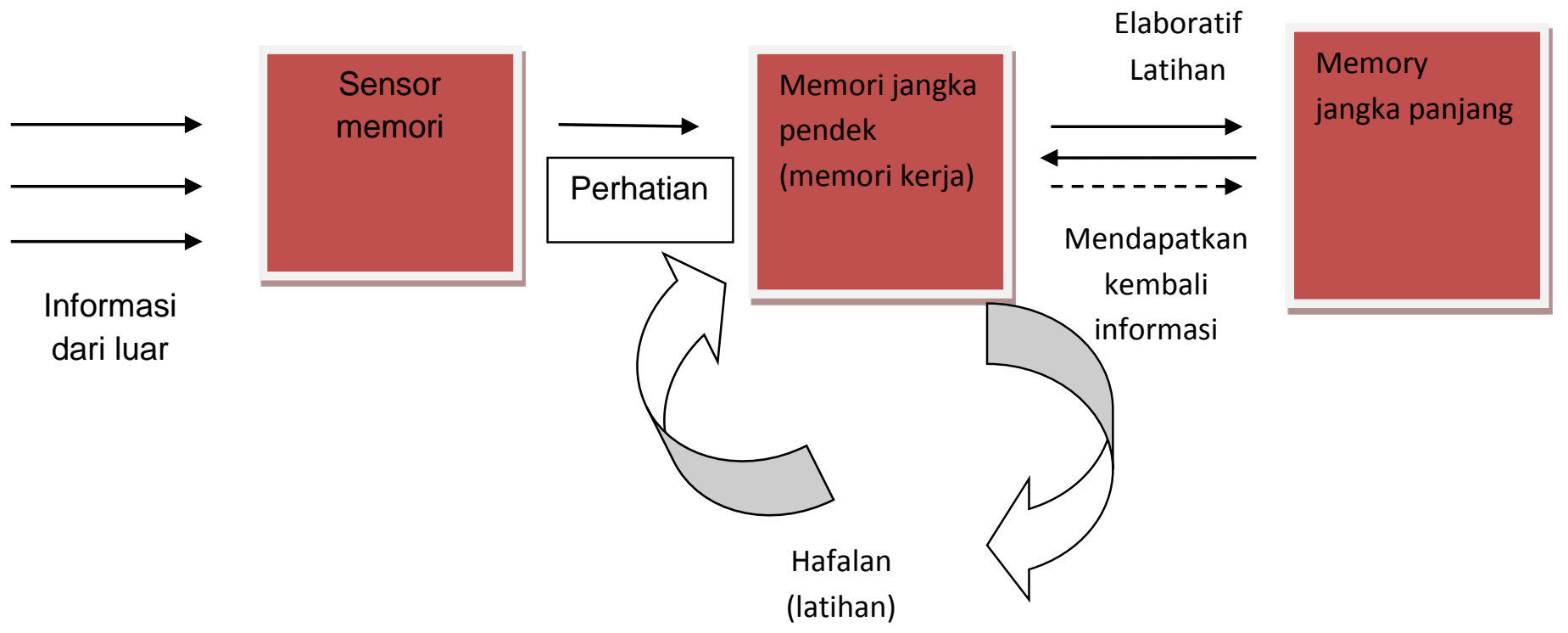

Gambar 2. Model tiga kotak dari memori (brown) 
Dari gambar 2, proses mendengarkan melewat ilima tahap: sensorik memori, perhatian, jangka pendek (bekerja) memori, latihan, dan memori jangka panjang. Model lima tahap mendengarkan sesuai dengan model yang sama yang diajukan oleh Klatzky (980). Menurut klatzky, proses mendengarkan yang terjadi melalui tahapan informasi masuk, pengenalan pola, informasi masuk, latihan, dan aplikasi informasi. Dua model dari proses mendengarkan menyarankan pentingnya perhatian (pengenalan pola dan latihan. Hal ini menunjukkan bahwa dalam menyimak siswa perlu berada didilibatkan dalam kegiatan menyimak yang membutuhkan perhatian penuh mereka. Selain itu, peluang harus diberikan kepada siswa untuk menyimak materi mendengarkan berulang kali sehingga mereka harus mengakui baik suara berbicara Bahasa dan disampaikan dalam bahasa mereka.

Reeta Sonawat mendiskripsikan fungsi bahasa untuk Anak adalah sebagai berikut:

1. Bahasa sebagai sarana untuk membuat keinginan dan kebutuhan dikenali

Awalnya anak mencoba untuk menyampaikan dan memenuhi kebutuhannya hanya dengan beberapa tanda-tanda dan simbol kemudian ia menyadari bahwa ada banyak situasi yang tidak bisa dipuaskan dengan cara ini. Ini berarti ia mulai menggunakan bahasa untuk mengekspresikan kebutuhan dan perasaannya dengan tepat.
2. Bahasa sebagai sarana untuk mengekspresikan emosi

Tertawa, mengguman, dan menangis merupakan sarana utama bagi bayi untuk mengekspresikan kesenangan dan ketidaksenangan. Awalnya ini untuk mengungkapkan perasaannya secara langsung yaitu secara fisik dengan tindakan tanpa kata-kata. Selama tahuntahun prasekolah pergeseran penting terjadi, anak mengungkapkan secara langsung, bukan dengan fisik namun jauh lebih simbolis dengan ekspresi emosinya. Misalnya: bukannya memukul dia mulai menggunakan kata-kata memukul.

3. Bahasa sebagai alat untuk memperoleh informasi.

Mengajukan pertanyaan dan mendapatkan jawaban merupakan kegiatan yang penting dalam periode ini. ia belajar tentang dunia di sekelilingnya dengan mengajukan pertanyaan.

4. Bahasa sebagai sarana untuk berinteraksi sosial.

Anak usia dini sangat termotivasi untuk terlibat dalam perilaku sosial. Anak prasekolah belajar bahwa ia harus bergantung pada orang lain untuk banyak hal. Interaksi sosial perlu untuk menambah keterampilan dalam berkomunikasi dengan orang lain. Bahasa adalah perekat dasar yang mengikat masyarakat bersama-sama. Melalui bahasa kita dapat menetapkan peran,dan hal tersebut adalah dasar organisasi. Melalui bahasa kita dapat membuat kesepakatan dengan orang lain.

5. Bahasa sebagai bantuan untuk mengidentifikasi pribadi. Setiap orang memiliki Keinginan untuk 
diakuioleh orang lain. Melalui bahasa dapat mengidentifikasi pribadi.

\section{Pengertian Gudget}

Gudget merupakan sebuah inovasi dari teknologi terbaru dengan kemampuan yang lebih baik dan fitur terbaru yang memiliki tujuan maupun fungsi lebih praktis dan juga lebih berguna. Seiring perkembangan pun menjadi berkembang yang sering kali menganggap smartphone adalah sebuah gudget dan juga teknologi komputer atau pun laptop bila telah diluncurkan produk baru juga dianggap sebagai gudget. Gudget (Bahasa Indonesia: acang) adalah suatu istilah yang berasal dari bahasa Inggris untuk merujuk pada suatu peranti atau instrumen yang memiliki tujuan dan fungsi praktis spesifik yang berguna yang umumnya diberikan terhadap sesuatu yang baru. Gudget Gratis dianggap dirancang secara berbeda dan lebih canggih dibandingkan teknologi normal yang ada pada saat penciptaannya.

Gudget adalah sebuah benda (alat atau barang eletronik) teknologi kecil yang memiliki fungsi khusus, tetapi sering diasosiasikan sebagai sebuah inovasi atau barang baru. Gudget selalu diartikan lebih tidak biasa atau didisain secara lebih pintar dibandingkan dengan teknologi normal pada masa penemuannya. Gudget merupakan salah satu teknologi yang sangat berperan pada era globalisasi ini. Sekarang gudget bukanlah benda yang asing lagi, hampir semua orang memilikinya. Tidak hanya masyarakat perkotaan, gudget juga dimiliki oleh masyarakat pedesaan.

Jadi Gudget merupakan sebuah alat eletronik yang merupakan sebuah hasil inovasi yang digunakan untuk memudahkan pekerjaan alat bantu, manipulasi, dan pengelolaan informasi. Sedangkan teknologi komunikasi adalah segala sesuatu yang berkaitan dengan penggunaan alat bantu untuk memproses dan mentransfer data dari perangkat yang satu ke lainnya. Memang benar bahwa mempunyai kelebihan dalam mendapatkan informasi yang di dapat dimana saja dan kapan saja. Namun kita tidak bisa melihat perkembangan dan peranan TIK dari satu prespektif saja. Ketika kita melihat dari prespektif lain terlihat bahwa terdapat ketimpangan sosial dan berbagai masalah yang terdapat pada penggunaan TIK pada anak usia dini. Gudget adalah salah satu dari ICT yang harus di perhatikan dampaknya terhadap perkembangan anak usia dini.

\section{Dampak Positif Gudget Bagi Perkembangan Bahasa Anak Usia Dini:}

\section{a. Kemampuan membaca}

Bagi anak yang belum lancar membaca, game konsol bisa jadi alat yang tepat untuk membantu belajar membaca. Seperti di ketahui ada beberapa game ada yang bersifat edukasi dan bisa membantu anak untuk belajar dengan cara yang lebih asyik. Selain itu, saat bermain anak juga diharuskan membaca setiap perintah yang diberikan oleh tokoh game dan 
narator game. Maka, secara tak langsung anak bisa belajar membaca dan mengeja secara signifikan.

\section{b. Pengenalan bahasa kedua (B2)}

Salah satu game anak yang disukai adalah game online. game ini banyak dibuat oleh perusahaan luar negeri yang mempergunakan bahasa Inggris. Saat memainkannya, diharuskan untuk menguasai bahasa Inggris agar bisa menyelesaikan permainannya. hal ini menjadikan anak secara tak langsung diharuskan untuk menguasai bahasa Inggris

\section{Dampak Negatif Gudget Bagi Perkembangan Bahasa Anak Usia Dini:}

a. Mengganggu Perkembangan Bahasa Reseptif

Yang dimaksud dengan bahasa reseptif adalah bahasa pasif, pengembangan Bahasa reseptif untuk anak usia dini adalah membantu anak mengembangkan kemampuan mendengarkan, contohnya mendengarkan cerita, nyanyian dan sebagainya, Meningkatkan kemampuan untuk merespon pembelajaran langsung contohnya bagaimana anak dapat menjawab atau merespon pertanyaan yang diajukan oleh guru, Membantu anak untuk mereaksi setiap komunikasi lainnya contohnya anak dapat memberi respon atau reaksi ketika ia berinteraksi dengan lingkungannya baik dengan guru, orang tua atau teman sebayanya. Faktanya dengan gudget anak hanya tertari dengan fitur-fitur yang membuat

mereka tidak berminat untuk berinteraksi dengan lingkungannya.

b. Menganggu Perkembangan Bahasa ekspresif

Bahasa reseptif merupakan kemampuan untuk mengekspresikan. Pada anak usia dini kemampuan ini diharapkan agar anak mampu membantu anak mengekspresikan kebutuhan, keinginan dan perasaan secara verbal, Mendorong anak untuk berbicara secara lebih jelas dan tegas sehingga mudah dipahami. Mendorong kepasihan berbahasa. Membantu anak memahami bahwa komunikasi tesebut dapat berpengaruh secara lebih efektif terhadap lingkungan sosial dan lingkungan anak.

c. Dengan adanya gudet anak kurang mampu menggunakan Bahasa Indonesia dengan baik.

d. Menghambat pengenalan Perkembangan Bahasa pertama pada anak usia dini (B1).

e. Anak tidak mampu berkomunikasi non verbal

Hal ini disebabkan gudget menyita waktu anak dengan game sehingga menghambat anak untuk mengeksresikan perasaan dan emosinya melalui ekspresi wajah, men geksresikan keinginan dan kebutuhannya melalui gerak tubuh dan tangan.

f. Gudget juga tidak mendorong anak untuk menggunakan kontak mata ketika berinteraksi dengan orang lain.

\section{Simpulan}


Teknologi informasi meliputi segala hal yang berkaitan dengan proses, penggunaan sebagai alat bantu, manipulasi, dan pengelolaan informasi. Sedangkan teknologi komunikasi adalah segala sesuatu yang berkaitan dengan penggunaan alat bantu untuk memproses dan mentransfer data dari perangkat yang satu ke lainnya. Memang benar bahwa TIK mempunyai kelebihan dalam mendapatkan informasi yang di dapat dimana saja dan kapan saja. Namun kita tidak bisa melihat perkembangan dan peranan TIK dari satu prespektif saja. Ketika kita melihat dari prespektif lain terlihat bahwa terdapat ketimpangan sosial dan berbagai masalah yang terdapat pada penggunaan TIK pada anak usia dini. Gudget adalah salah satu dari ICT yang sangat berperan penting terhadap perkembangan anak usia dini.

Gudget merupakan sebuah alat eletronik yang merupakan sebuah hasil inovasi yang digunakan untuk memudahkan pekerjaan alat bantu, manipulasi, dan pengelolaan informasi. Sedangkan teknologi komunikasi adalah segala sesuatu yang berkaitan dengan penggunaan alat bantu untuk memproses dan mentransfer data dari perangkat yang satu ke lainnya. Memang benar bahwa mempunyai kelebihan dalam mendapatkan informasi yang di dapat dimana saja dan kapan saja. Namun kita tidak bisa melihat perkembangan dan peranan TIK dari satu prespektif saja. Ketika kita melihat dari prespektif lain terlihat bahwa terdapat ketimpangan sosial dan berbagai masalah yang terdapat pada penggunaan TIK pada anak usia dini. Gudget adalah salah satu dari ICT yang sangat harus diperhatikan terhadap perkembangan anak usia dini.

\section{DAFTAR REFERENSI}

Bambang Yudi Cahyono and Utami Widiati. 2011. As teaching of a foreighn language in Indonesia. Malang.State University of making Press.

Eva L. Essa . 2011. Early Childhood Education Sixth Edition (Wadsworth Cengage Learning: Univeristy Of Nevada).

Morrisson. George S. 2012. Dasar-Dasar Pendidikan Anak Usia Dini (PAUD), Jakarta:Indeks.

Mulyasa. 2012. Manajemen PAUD. Bandung : Rosdakarya

Mutiah. Diana. 2012. Psikologi Bermain Anak Usia Dini. Jakarta: Kencana Prenada Media Group

Papalia ,Diane E.. 2012. Perience Human Development (Mc Graw Hill: United States America.

Reeta Sonawat dan Jasmine Maria Francis. 2017. Language Development for Preschool Children .Mumbai:

Abhinav Enterprises.

Widiawati dan Sugiman. 2014. Pengaruh penggunaan gudget terhadap daya kembang anak. Diakses darihttp://stmikglobal.ac.id/wpcontent/ uploads /2014/05/ ARTIKELIIS.pdf pada tanggal 10 Desember 2016. 
Yulsyofriend $^{1}$, Vivi Anggraini ${ }^{2}$, Indra Yeni ${ }^{3}$ 